\title{
Perjanjian Kawin Sebagai Bentuk Perlindungan Hukum Bagi Pasangan Suami Istri (Perspektif Maqashid Syari'ah)
}

\author{
Dyah 0chtorina Susanti* \\ Universitas Jember \\ Email: dyahochtorina.fh@unej.ac.id
}

\begin{abstract}
The marriage agreement in Indonesia, regulates the property in marriage and the possessions of married couples. Empirical facts show that the marital couple disputes are not only caused by differences in property, but also triggered by other causes. This study aims to find and analyze and provide an understanding that the marriage agreement should not only be done to regulate property but rather lead to the rights and obligations and interests maqashid shariah. To the government and the House of Representatives, should make renewal of the marriage agreement agreement, not only contains the agreement about the property alone, but firmly explained that married couples can make a marriage agreement outside the agreement on the property. Should be made a separate rule that contains explicitly about the marriage agreement by considering the side of utilities (benefit) and based on maqashid shari'ah, and from the side of legal certainty that leads to the guarantee of protection for married couples.
\end{abstract}

Keywords : Marriage Agreement, Legal Protection, Husbandry Wife, Maqashid Syari'ah.

* Dosen Fakultas Hukum, Universitas Jember, Jawa Timur, Indonesia. 


\begin{abstract}
Abstrak
Perjanjian kawin di Indonesia, mengatur tentang harta dalam perkawinan dan harta bawaan dari pasangan suami istri. Fakta empiris menunjukkan bahwa perselisihan pasangan suami istri tidak hanya disebabkan oleh perbedaan harta, akan tetapi juga dipicu sebab lainnya. Penelitian ini bertujuan menemukan dan menganalisa serta memberikan pemahaman bahwa perjanjian kawin sebaiknya tidak saja dilakukan untuk mengatur harta tetapi lebih mengarah kepada hak dan kewajiban serta kepentingan maqashid syari'ah. Kepada pemerintah dan DPR RI, hendaknya mengadakan pembaharuan terhadap susbtansi perjanjian kawin, tidak hanya memuat perjanjian tentang harta saja, melainkan tegas diterangkan bahwa pasangan suami istri dapat melakukan perjanjian kawin diluar perjanjian tentang harta. Hendaknya dibuat aturan tersendiri yang memuat secara tegas tentang perjanjian kawin dengan mempertimbangkan sisi utilities (kemanfaatan) serta berdasar maqashid syari'ah, dan dari sisi kepastian hukum yang bermuara pada jaminan perlindungan bagi pasangan suami istri.
\end{abstract}

Kata Kunci : Perjanjian Kawin, Perlindungan Hukum, Suami Istri, Maqāshid al-Sharī'ah

\title{
Pendahuluan
}

Keluarnya putusan Mahkamah Agung No. 69/PUUXIII/2015 di Bulan Oktober 2016, membawa pergeseran makna dan pergeseran norma hukum. Istilah perjanjian kawin dalam norma hukum di Indonesia diatur pada Bab Ketujuh, Bagian Kesatu, Pasal 139 sampai Pasal 154 Burgerlijk Wetboek atau yang dikenal dengan sebutan Kitab Undang-Undang Hukum Perdata (selanjutnya disingkat menjadi KUHPerdata), pada perkembangan selanjutnya pada tahun 1974 lahirlah UndangUndang No. 1 Tahun 1974 Tentang Perkawinan (selanjutnya disingkat menjadi UU Perkawinan), yang juga mengatur tentang perjanjian kawin pada Bab V Pasal 29. UU Perkawinan ini merupakan hukum pertama yang mengatur tentang perkawinan

Ulul Albab: Jurnal Studi dan Penelitian Hukum Islam 
Perjanjian Kawin Sebagai Bentuk .... $\mid 3$

yang "berdasarkan" hukum Islam. ${ }^{1}$ Terkait dengan norma hukum perkawinan yang berdasarkan hukum Islam, pada tahun 1991, pemerintah melalui Instruksi Presiden No. 1 Tahun 1991 Tentang Penyebarluasan Kompilasi Hukum Islam (selanjutnya disingkat menjadi $\mathrm{KHI}$ ), juga mengatur mengenai perjanjian kawin. Perjanjian kawin pada KHI diatur pada Bab VII Pasal 45 sampai pasal 52.

Perjanjian kawin memiliki sampai saat ini memiliki definisi yang beragam. Soetojo Prawiromidjojo dan Asis Safioedin, menjelaskan bahwa perjanjian kawin adalah perjanjian yang dibuat oleh calon suami istri sebelum atau pada saat dilangsungkan perkawinan untuk mengatur akibat-akibat perkawinan terhadap harta kekayaan mereka. ${ }^{2}$ Senada dengan Soetojo Prawiromidjojo dan Asis Safioedin, R. Subekti juga menjelaskan bahwa perjanjian perkawinan adalah suatu perjanjian mengenai harta benda suami istri selama perkawinan mereka yang menyimpang dari asas atau pola yang ditetapkan oleh undang-undang. 3 Sejalan dengan definisi sebelumnya, Komar Andasasmita mengemukakan bahwa perjanjian perkawinan adalah perjanjian yang diadakan oleh bakal atau calon suami istri dalam mengatur (keadaan) harta benda atau kekayaan sebagai akibat dari perkawinan mereka. ${ }^{4}$ Pada intinya

${ }^{1}$ Jauh sebelum lahirnya UU No. 1 Tahun 1974, diawal kemerdekaan, Pemerintah Indonesia sudah berusaha melakukan perbaikan hukum di bidang perkawinan dan keluarga melalui UU No. 22 Tahun 1946 Tentang Pencatatan Nikah, Talak dan Rujuk bagi masyarakat yang beragama Islam. Terkait pelaksanaan UU tersebut, diterbitkanlah Instruksi Menteri Agama No. 4 Tahun 1946 yang ditujukan untuk pegawai pencatat nikah (PPN). Lihat Nani Suwondo, Kedudukan Wanita Indonesia Dalam Hukum dan Masyarakat, (Jakarta: Ghalia Indonesia, 1992), 77.

2 R. Soetojo Prawirohamidjojo dan Asis Safioedin, Hukum Orang dan Keluarga, (Bandung: Alumni,1987), 57.

${ }^{3}$ R. Soebekti, Pokok-Pokok Hukum Perdata, (Jakarta: Intermasa, 1994), 9.

${ }^{4}$ Komar Andasasmita, Notaris II Contoh Akta Otentik dan Penjelasannya, (Bandung: Ikatan Notaris Indonesia (INI) Daerah Jabar, 1990), 5. 
menurut pendapat penulis, perjanjian kawin ${ }^{5}$ memuat tentang kedudukan harta yang dimiliki oleh suami dan/atau istri.

Fakta empiris menunjukkan bahwa tidak semua pasangan suami istri paham tentang perjanjian kawin baik dari sisi makna maupun sisi substansinya. Berbagai kasus menunjukkan indikasi tersebut. Kasus perceraian yang dilatarbelakangi oleh beberapa alasan seperti permasalahan ekonomi, poligami, perselingkuhan, menjadi pemicu terjadinya konflik antar pasangan suami istri. Hal tersebut terbukti dari beberapa putusan Pengadilan Agama, diantaranya kasus perceraian pertama, yang terdapat dalam Putusan Nomor 251/Pdt.G/2017/PA.Skh, dimana penyebab perceraian tersebut dikarenakan adanya permasalahan ekonomi. ${ }^{6}$ Kasus kedua, yakni terdapat di dalam putusan Nomor 0836/Pdt.G/2017/PA Bta, yang menjelaskan bahwa penyebab perceraian pada kasus tersebut terjadi karena si suami menikah dengan perempuan lain

${ }^{5}$ Sebagai bahan perbandingan, pada hukum perdata yang berlaku di Indonesia, terdapat beberapa bentuk perjanjian kawin antara lain : 1. Perjanjian perkawinan diluar persekutuan harta benda atau harta terpisah berupa apapun juga; 2. Perjanjian perkawinan persatuan untung dan rugi; 3. Perjanjian perkawinan persatuan hasil dan pendapatan. Lihat Alwesius. Pembuatan Perjanjian Perkawinan Pasca Putusan Mahkamah Konstitusi, http://www.notary.my.id/2016/11/pembuatanperjanjian-perkawinan-pasca.html, diakses Senin, 24 Sepetember 2017.

${ }^{6} \mathrm{Hal}$ ini dapat dilihat dalam gugatan sang istri yang mengemukakan bahwa sang suami malas bekerja dan tidak memberikan nafkah kepada si istri, sehingga si istri lah yang bekerja sebagai karyawan swasta untuk mencukupi kebutuhan sehari-hari. Melihat si istri bekerja, si suami sering meminta uang kepada si istri, dan apabila tidak diberi, si suami mengambil uang istrinya tersebut secara diam-diam. Tidak hanya itu, bahkan si suami menggadaikan sepeda motor milik si istri tanpa sepengetahuan dan seizin istrinya tersebut. Si istri lantas tidak hanya diam, namun ia mencoba untuk menyadarkan si suami, namun si suami memberontak hingga berujung perselisihan dan pertengkaran. Si suami sering membentak-bentak istrinya dengan kata-kata kasar, bahkan ia pernah memukul mata si istri hingga lebam. Terkait demikian, karena tidak tahan, si istri kemudian melayangkan gugatan perceraian terhadap suaminya tersebut. https://putusan.mahkamahagung.go.id/main/pencarian/?q=251\%2FPdt.G\%2F201 7\%2FPA.Skh, diakses pada tanggal 16 Februari 2018.

Ulul Albab: Jurnal Studi dan Penelitian Hukum Islam 
Perjanjian Kawin Sebagai Bentuk .... $\mid$

tanpa persetujun si istri. ${ }^{7}$ Penyebab terjadinya perceraian, ternyata tidak hanya disebabkan karena adanya pelanggaran hak dan kewajiban dari pihak suami, akan tetapi juga dapat disebabkan karena perilaku si istri. Hal ini dapat dilihat dari kasus ketiga dalam putusan Pengadilan Agama Baturaja Nomor 0907/Pdt.G/2017/PA.Bta, yang mengemukakan bahwa perceraian tersebut timbul karena si istri tidak patuh terhadap suaminya, dan berani berselingkuh dengan laki-laki lain. ${ }^{8}$

Fakta empiris menunjukkan bahwa perceraian suami istri tidak hanya terkait hal-hal yang bersifat materialistik (baca: harta), akan tetapi banyak hal-hal diluar materialistik (baca: Harta), tidak hanya istri yang dirugikan akan tetapi pihak suami juga mendapat kerugian pada saat terjadi perceraian. Terkait kerugian yang diderita pasangan suami istri sejak awal perkawinan bisa diantisipasi dengan perjanjian kawin. Menjadi masalah adalah perjanjian kawin di Indonesia hanya memuat konsep pemisahan harta tanpa mengatur hal-hal yang sekiranya patut diperjanjikan di depan agar tidak menimbulkan konflik

${ }^{7}$ Suami istri yang menikah pada 25 Desember 2011, awalnya merupakan keluarga harmonis sebagaimana keluarga-keluarga bahagia lainnya. Semenjak bulan April 2015, keharmonisan tersebut pudar dan mulai terjadi pertengkaran yang disebabkan karena si suami tidak memberi nafkah kepada si istri. Hal itu kemudian menimbulkan kecurigaan si istri akan tingkah laku si suami yang mulai berubah, hingga pada bulan Desember 2015, si istri baru mengetahui penyebab perilaku suaminya tersebut, yakni dikarenakan si suami ternyata telah menikah lagi dengan wanita lain tanpa sepengetahuan istrinya tersebut. Mendengar hal itu, si istri kemudian mengajukan gugatan cerai di Pengadilan Agama Baturaja. https:/putusan.mahkamahagung.go.id/main/pencarian/?q=0836\%2FPdt.G\%2F20 17\%2FPA+Bta, diakses pada tanggal 16 Februari 2018.

${ }^{8}$ Kronologi adanya perceraian antara pasangan suami istri, dimana pasangan tersebut kerap mengalami perselisihan dan pertengkaran yang disebabkan karena si istri tidak patuh terhadap suaminya. Pertengkaran pun memuncak ketika pada tanggal 12 April 2017, si suami memergoki istrinya sedang bersama dengan laki-laki lain yang merupakan selingkuhan istrinya tersebut. https://putusan.mahkamahagung.go.id/main/pencarian/?q=0907\%2FPdt.G\%2F20 17\%2FPA.Bta, diakses pada tanggal 16 Februari 2018.

Vol. 1, No. 2, April 2018, 1-30 
6 Diyah Octhorina Susanti

bagi pasangan yang akan membina perkawinan. Hal demikian yang medorong penulis menulis artikel ilmiah dengan tema sentral "Perjanjian Kawin Sebagai Bentuk Perlindungan Hukum Bagi Pasangan Suami Istri (Perspektif Maqashid Syari'ah)".

\section{Metode Penelitian}

\section{a) Jenis Penelitian dan Pendekatan}

Jenis Penelitian ini merupakan penelitian hukum normatif (normatif legal research) untuk mengurai konsep perjanjian kawin sebagai bentuk perlindungan hukum bagi pasangan suami istri. Penelitian hukum normatif disebut juga dengan istilah penelitian kepustakaan, yang fokus pada analisis bahan primer dan sekunder. ${ }^{9}$ Soejono dan Abdurrahman menyebut penelitian hukum normatif sebagai penelitian doktrinal, yaitu: penelitian yang objek kajiannya adalah dokumen peraturan perundang-undangan dan bahan pustaka. ${ }^{10}$ Penelitian ini juga bersifat sistematis mengenai aturan hukum yang mengatur bidang hukum tertentu, menganalisis hubungan antara aturan hukum yang satu dengan yang lain, menjelaskan bagian-bagian yang sulit untuk dipahami dari suatu aturan hukum tertentu, bahkan mungkin juga mencakup prediksi perkembangan suatu aturan hukum tertentu pada masa mendatang. ${ }^{11}$ Terkait dengan tullisan artikel ini, aturan hukum yang dimaksud adalah aturan hukum terkait dengan perjanjian kawin.

Berkaitan dengan pendekatan yang relevan digunakan dalam penelitian ini adalah pendekatan perundang-undangan

${ }^{9}$ Bahan hukum primer adalah bahan hukum yang bersifat mengikat, contohnya peraturan perundang-undangan. Terkait bahan hukum sekunder meliputi buku-buku hukum, kamus hukum, jurnal, disertasi, dan lain sebagainya. Lihat Dyah Ochtorina Susanti dan A'an Efendi. Penelitian Hukum (Legal Research). (Jakarta: Sinar Grafika, 2014), 52.

10 Soejono dan Abdurrahman, Metode Penelitian Hukum, (Jakarta: Rineka Cipta, 2003), 56.

${ }^{11}$ Dyah Ochtorina Susanti dan A'an Efendi, Penelitian Hukum..., 11.

Ulul Albab: Jurnal Studi dan Penelitian Hukum Islam 
dan pendekatan konsep. Pendekatan perundang-undangan dilakukan dengan menelaah semua undang-undang dan regulasi yang berkenaan dengan isu hukum yang diketengahkan. ${ }^{12}$ Hasil telaah yang dilakukan kemudian menjadi argumen untuk memecahkan isu hukum yang dihadapi. Berkenaan dengan hal tersebut, dalam penelitian ini, pendekatan perundang-undangan digunakan untuk menelaah peraturan perundang-undangan yang mengatur mengenai perjanjian kawin sebagai bentuk perlindungan hukum terhadap pasangan suami istri. Adapun pendekatan konseptual dilakukan manakala peneliti tidak beranjak dari aturan hukum yang ada, dan hal tersebut dilakukan karena belum ada atau tidak ada aturan hukum untuk masalah yang dihadapi. Terkait demikian, pada saat menggunakan pendekatan konseptual, peneliti perlu merujuk prinsip-prinsip hukum yang dapat ditemukan dalam pandangan para sarjana hukum ataupun doktrin-doktrin hukum. ${ }^{13}$ Pada artikel ini diperlukan pendekatan konseptual untuk menguraikan konep perjanjian kawain yang ada saat ini dan konsep perjanjian kawin yang akan menjadi preskripsi pada bagian akhir artikel ini.

\section{b) Jenis dan Sumber Bahan Hukum}

Bahan-bahan hukum yang digunakan untuk dapat menemukan jawaban atas isu hukum mengenai urgensi pencatatan perkawinan mencakup :

1) Bahan Hukum Primer yaitu bahan hukum yag memiliki otoritas (Authority), artinya bersifat mengikat terdiri atas : ${ }^{14}$

a. Burgelijk Wetboek (dalam bahasa Indonesia disebut Kitab Undang-Undang Hukum Perdata)

b. Undang-Undang Nomor 1 Tahun 1974 Tentang Perkawinan. .

\footnotetext{
${ }^{12}$ Peter Mahmud Marzuki, Penelitian Hukum, (Jakarta: Prenada Media,
} 2005), 93.

${ }^{13}$ Dyah Ochtorina Susanti dan A'an Efendi, Penelitian Hukum..., 115.

${ }^{14}$ Ibid., 52. 
c. Instruksi Presiden No. 1 Tahun 1991 Tentang Penyebarluasan Kompilasi Hukum Islam.

2) Bahan hukum sekunder yaitu bahan yang menjelaskan bahan hukum primer, seperti: hasil penelitian, jurnal ilmiah, hasil seminar atau penemuan ilmiah lainnya, ${ }^{15}$ yang memberikan tinjauan luas tentang pokok persoalan dan mengidentifikasi perundang-undangan, regulasi, ketentuan-ketentuan pokok, dan kasus-kasus penting berkaitan dengan topik penelitian. ${ }^{16}$

3) Bahan hukum tersier, yaitu bahan hukum sebagai penunjang yang memberi petunjuk dan penjelasan terhadap bahan hukum primer dan bahan hukum sekunder, seperti kamus hukum dan kamus bahasa Indonesia. ${ }^{17}$

\section{c) Teknik Penelusuran Bahan Hukum}

Pada Penelitian ini pengumpulan dan penelusuran bahan hukum dilakukan dengan menggunakan metode kepustakaan sistematis, yaitu penelusuran dokumen terkait dengan konsep perjanjian perkawinan di Indonesia dan maqashid syari'ah. Informasi yang di dapat dari penelitian ini kemudian akan dianalisa dengan menggunakan metode analisis isi (content analisis) ${ }^{18}$ baik dalam menganalisa konsep perjanjian kawin maupun kaitannya dengan teori maqashid syari'ah.

\section{Pembahasan}

Setiap mahluk hidup memiliki hak asasi untuk melanjutkan keturunannya melalui perkawinan. Perkawinan adalah ikatan lahir batin antara seorang pria dan seorang wanita sebagai suami istri dengan tujuan membentuk keluarga atau rumah tangga yang bahagia dan kekal berdasarkan Ketuhanan

\footnotetext{
${ }^{15}$ Ibid., 19.

${ }^{16}$ Ibid., 90.

17 Soerjono Soekanto dan Sri Mamudji, Penelitian Hukum Normatif: Suatu Tinjauan Singkat, (Jakarta: Rajawali Pers, 2004), 13.

${ }^{18}$ Valerina JL. Kriekhoff, “Analisis Konten Dalam Penelitian Hukum: Suatu Telaah Awal”, Jurnal Era Hukum, No, 6, 2002, 22.
}

Ulul Albab: Jurnal Studi dan Penelitian Hukum Islam 
Yang Maha Esa. ${ }^{19}$ Pada tataran hukum Islam, perkawinan diartikan sebagai pernikahan atau akad yang sangat kuat atau mitsaqah galidzan untuk mentaati perintah Allah dan melaksanakannya merupakan ibadah, dengan tujuan untuk mewujudkan kehidupan rumah tangga yang sakinah, mawaddah dan rahmah..$^{20}$ Faktanya, tidak semua perkawinan berjalan sesuai dengan yang diharapkan yakni terwujudnya kehidupan keluarga (berumah tangga) yang damai, bahagia, harmonis, dan kekal selama-lamanya. Faktor ketidakcocokan satu sama lain seringkali mempengaruhi bahtera perkawinan, sehingga terkadang ada rasa kekhawatiran pasangan suami istri atas hal-hal yang mungkin terjadi dalam rumah tangga yang berujung timbulnya perceraian.

Sehubungan dengan hal tersebut, saat ini tidak sedikit pasangan suami istri yang mengikat perkawinannya dengan sebuah perjanjian, guna mencegah hal-hal yang tidak diinginkan dalam sebuah perkawinan. Perjanjian secara etimologis, yang dalam Bahasa Arab diistilahkan dengan Mu'ahadah Ittifa' atau Akad, adalah suatu perbuatan di mana seseorang atau lebih mengikatkan dirinya terhadap seseorang lain atau lebih. ${ }^{21}$ Secara terminologi figh, akad didefinisikan sebagai pertalian ijab dan qobul22 sesuai dengan kehendak syariat yang berpengaruh pada

19 Lihat Pasal 1 Undang-Undang Nomor 1 Tahun 1974 Tentang Perkawinan.

${ }^{20}$ Lihat Pasal 2 dan 3 Instruksi Presiden Republik Indonesia Nomor 1 Tahun 1991 Tentang Penyebarluasan Kompilasi Hukum Islam.

${ }^{21}$ Chairuman Pasaribu dan Suhrawardi K. Lubis, Hukum Perjanjian Dalam Islam, (Jakarta: Sinar Grafika, 2004), 1.

${ }^{22}$ Ijab adalah pernyataan pihak pertama mengenai isi perikatan yang diinginkan sedangkan qabul adalah penyataan pihak kedua untuk menerimanya. Lihat Achmad Azhar Basyir, Asas-Asas Hukum Muamalat, (Yogyakarta: UII Press, 2000), 65. 
$10 \mid$ Diyah Octhorina Susanti

objek perikatan. ${ }^{23}$ Pada hukum positif yakni Kitab UndangUndang Hukum Perdata menegaskan bahwa perjanjian adalah suatu perbuatan dengan mana satu orang atau lebih mengikatkan dirinya terhadap satu orang lain atau lebih. ${ }^{24}$

Definisi lain terkait perjanjian juga dikemukakan oleh beberapa para ahli, diantaranya menurut WJS. Poerwadarminta dalam Kamus Umum bahasa Indonesia dalam Chairuman Pasaribu dan Suhrawardi K. Lubis, perjanjian diartikan sebagai suatu persetujuan (tertulis atau dengan lisan) yang dibuat oleh dua pihak atau lebih yang mana berjanji akan menaati apa yang tersebut di persetujuan itu....". ${ }^{25}$ Wirjono Podjodikoro dalam Damanhuri, memberikan definisi perjanjian yaitu suatu hubungan hukum mengenai harta benda kekayaan antara dua pihak, dalam mana satu pihak berjanji atau dianggap berjanji untuk melakukan sesuatu hal, sedang pihak lain berhak menuntut pelaksanaan janji itu. ${ }^{26}$ Wirjono Projodikoro dalam Damanhuri juga mengemukakan bahwa perkawinan merupakan suatu perjanjian apabila seorang perempuan dan seorang laki-laki berkata sepakat untuk melakukan perkawinan satu sama lain, dimana pasangan tersebut saling berjanji akan taat pada peraturan-peraturan hukum yang berlaku mengenai hak-hak dan kewajiban masing-masing pihak selama dan sesudah hidup bersama itu berlangsung, dan mengenai kedudukan dalam masyarakat dari anak-anak keturunannya. ${ }^{27}$

23 Cindawati, "Perkembangan Perjanjian Baku dalam Praktik Perdagangan: Perspektif Hukum Islam dan Perspektif Hukum Positif". Jurnal Jurisdictie Jurnal Hukum dan Syari'ah, Vol. 7 No.2, Desember 2016, 221.

${ }^{24}$ Lihat Pasal 1313 Kitab Undang-Undang Hukum Perdata dalam Subekti dan Tjitrosudibio, Kitab Undang-Undang Hukum Perdata, (Jakarta: PT. Pradnya Paramita, 1996), 338.

${ }^{25}$ Chairuman Pasaribu dan Suhrawardi K. Lubis, Hukum Perjanjian..., 1.

${ }^{26}$ Damanhuri, Segi-Segi Hukum Perjanjian Perkawinan Harta Bersama, (Bandung: CV. Mandar Maju, 2012), 1.

${ }^{27}$ Damanhuri, Segi-Segi Hukum..., 2.

Ulul Albab: Jurnal Studi dan Penelitian Hukum Islam 
Berkaitan dengan definisi perjanjian perkawinan tidak dijelaskan secara eksplisit di dalam perundang-undangan, melainkan secara implisit diatur di dalam beberapa peraturan perundang-undangan. Peraturan yang pertama kali mengatur perjanjian perkawinan yaitu tercantum di dalam pasal 139-154 Kitab Undang-Undang Hukum Perdata (selanjutnya disingkat KUHPerdata), kemudian dilanjutkan dengan terbitnya UndangUndang Nomor 1 Tahun 1974 Tentang Perkawinan (selanjutnya disebut UU Perkawinan) tepatnya pada Pasal 29 UU Perkawinan, dan Pasal 45-52 Instruksi Presiden Republik Indonesia Nomor 1 Tahun 1991 Tentang Penyebarluasan Kompilasi Hukum Islam (selanjutnya disebut KHI). Berikut persamaan dari ketiga peraturan perundang-undangan yang mengatur tentang perjanjian perkawinan:

Tabel 1

Persamaan Pengaturan Perjanjian Perkawinan

\begin{tabular}{|c|c|c|c|}
\hline $\begin{array}{l}\text { Isi Perjanjian } \\
\text { Kawin }\end{array}$ & KUHPerdata & $\begin{array}{c}\text { UU } \\
\text { Perkawinan }\end{array}$ & $\begin{array}{c}\text { Kompilasi } \\
\text { Hukum Islam }\end{array}$ \\
\hline $\begin{array}{l}\text { Mengatur } \\
\text { tentang } \\
\text { Persatuan } \\
\text { Harta } \\
\text { Kekayaan } \\
\text { (Harta } \\
\text { Bersama) }\end{array}$ & $\begin{array}{l}\text { Calon suami } \\
\text { istri berhak } \\
\text { menyiapkan } \\
\text { beberapa } \\
\text { penyimpang } \\
\text { an dari } \\
\text { peraturan } \\
\text { undang- } \\
\text { undang } \\
\text { sekitar } \\
\text { persatuan } \\
\text { harta } \\
\text { kekayaan, } \\
\text { asal } \\
\text { perjanjian }\end{array}$ & $\begin{array}{l}\text { Pada waktu } \\
\text { atau sebelum } \\
\text { perkawinan } \\
\text { dilangsungka } \\
\text { n, kedua pihak } \\
\text { atas } \\
\text { persetujuan } \\
\text { bersama dapat } \\
\text { mengadakan } \\
\text { perjanjian } \\
\text { tertulis yang } \\
\text { disahkan oleh } \\
\text { Pegawai } \\
\text { pencatat } \\
\text { perkawinan.... }\end{array}$ & $\begin{array}{l}\text { Perjanjian } \\
\text { perkawinan } \\
\text { meliputi } \\
\text { percampuran } \\
\text { harta pribadi } \\
\text { dan pemisahan } \\
\text { harta } \\
\text { pencaharian } \\
\text { masing- } \\
\text { masing } \\
\text { sepanjang hal } \\
\text { itu tidak } \\
\text { berentangan } \\
\text { dengan hukum } \\
\text { Islam. }\end{array}$ \\
\hline
\end{tabular}




\begin{tabular}{|c|c|c|c|}
\hline & $\begin{array}{l}\text { tidak } \\
\text { menyalahi } \\
\text { tata susilaan. } \\
\text { (Pasal 139) }\end{array}$ & (Pasal 29) & $\begin{array}{l}\text { (Pasal } 47 \text { ayat } \\
\text { 2) }\end{array}$ \\
\hline $\begin{array}{l}\text { Perjanjian } \\
\text { dilakukan } \\
\text { sebelum } \\
\text { perkawinan }\end{array}$ & $\begin{array}{l}\text { Atas } \\
\text { ancaman } \\
\text { kebatalan, } \\
\text { setiap } \\
\text { perjanjian } \\
\text { perkawinan } \\
\text { harus dibuat } \\
\text { dengan akta } \\
\text { notaris } \\
\text { sebelum } \\
\text { perkawinan } \\
\text { berlangsung. } \\
\text { (Pasal 47) }\end{array}$ & $\begin{array}{l}\text { Pada waktu } \\
\text { atau sebelum } \\
\text { perkawinan } \\
\text { dilangsungka } \\
\text { n, kedua pihak } \\
\text { atas } \\
\text { persetujuan } \\
\text { bersama dapat } \\
\text { mengadakan } \\
\text { perjanjian } \\
\text { tertulis yang } \\
\text { disahkan oleh } \\
\text { Pegawai } \\
\text { pencatat } \\
\text { perkawinan.... } \\
\text { (Pasal } 29 \text { ayat } \\
\text { 1) }\end{array}$ & $\begin{array}{l}\text { Pada waktu } \\
\text { atau sebelum } \\
\text { perkawinan } \\
\text { dilangsungkan } \\
\text { kedua calon } \\
\text { mempelai } \\
\text { dapat } \\
\text { membuat } \\
\text { perjanjian } \\
\text { tertulis yang } \\
\text { disahkan } \\
\text { Pegawai } \\
\text { Pencatat Nikah } \\
\text { mengenai } \\
\text { kedudukan } \\
\text { harta dalam } \\
\text { perkawinan. } \\
\text { (Pasal } 47 \text { ayat } \\
\text { 1) }\end{array}$ \\
\hline $\begin{array}{l}\text { Perjanjian tidak } \\
\text { bertentangan } \\
\text { dengan } \\
\text { kesusilaan, } \\
\text { agama }\end{array}$ & $\begin{array}{l}\text { Calon suami } \\
\text { istri berhak } \\
\text { menyiapkan } \\
\text { beberapa } \\
\text { penyimpang } \\
\text { an dari } \\
\text { peraturan }\end{array}$ & $\begin{array}{l}\text { Perjanjian } \\
\text { perkawinan } \\
\text { tidak dapat } \\
\text { disahkan } \\
\text { bilamana } \\
\text { melanggar } \\
\text { batas-batas }\end{array}$ & $\begin{array}{l}\text { Kedua calon } \\
\text { mempelai } \\
\text { dapat } \\
\text { mengadakan } \\
\text { perjanjian } \\
\text { perkawinn } \\
\text { dalam bentuk: }\end{array}$ \\
\hline
\end{tabular}

Ulul Albab: Jurnal Studi dan Penelitian Hukum Islam 


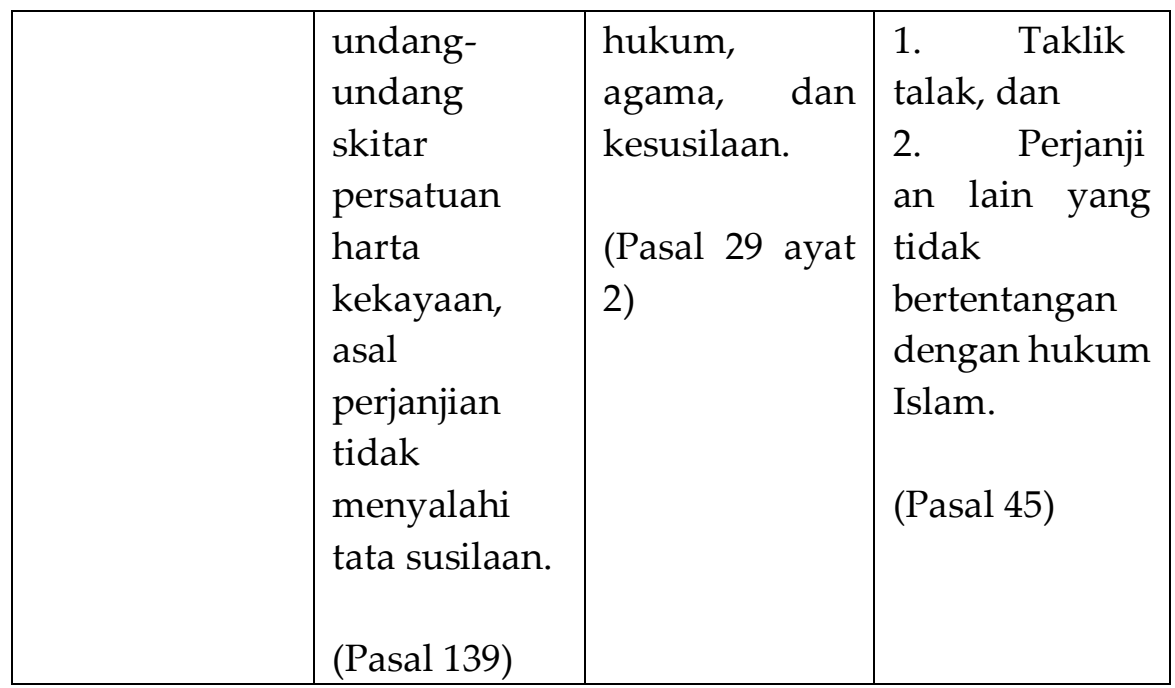

Sumber: Catatan Pribadi Penulis, diolah, 2018

Tabel diatas menunjukkan bahwa semua peraturan perudang-undangan terkait perjanjian perkawinan mengatur tentang harta kekayaan atau harta benda atau harta bersama. Pengaturan pada KUHPerdata misalnya, dalam Pasal 119 KUHPerdata dijelaskan bahwa pada saat perkawinan dilangsungkan demi hukum berlakulah persatuan bulat antara harta kekayaan suami dan istri. Persatuan sebagaimana yang dimaksud selama perkawinan tidak boleh diubah atau ditiadakan tanpa adanya kesepakatan dari suami ataupun istri. Berkenaan dengan demikian, apabila ketentuan terkait persatuan harta tersebut ingin disimpangi, maka pasangan suami istri harus menempuh jalan melalui perjanjian perkawinan sebagaimana yang diatur pada Pasal 139 KUHPerdata.

Senada dengan penjelasan di atas, walaupun perjanjian perkawinan terkait harta bersama di dalam UU Perkawinan tidak dikemukakan secara tegas, akan tetapi hal tersebut tersirat dalam beberapa pasal, salah satunya pada pasal $35 \mathrm{UU}$ Perkawinan yang menjelaskan bahwa harta benda selama 
perkawinan akan menjadi harta bersama dan harta bawaan dari masing-masing suami dan istri dan harta benda yang diperoleh masing-masing sebagai hadiah atau warisan adalah dibawah penguasaan masing-masing, kecuali para pihak menentukan hal lain. ${ }^{28}$ Ketentuan dalam hal ini dimaksudkan pada suatu perjanjian perkawinan, dimana pasangan suami istri dapat menentukan bahwa harta benda yang semula menjadi harta bersama, dengan persetujuan kedua belah pihak, maka dapat dilakukan pemisahan harta, bahkan terhadap harta bawaan, suami atau istri dapat melakukan perbuatan hukum mengenai harta bendanya masing-masing. ${ }^{29}$

Pengaturan perjanjian perkawinan selanjutnya diatur di dalam Instruksi Presiden R.I Nomor 1 Tahun 1991 tentang Penyebarluasan Kompilasi Hukum Islam (selanjutnya disebut $K H I)$, dimana perjanjian perkawinan mengenai harta bersama tercantum di dalam Pasal $47 \mathrm{KHI}$ yang menjelaskan bahwa perjanjian perkawinan tidak hanya terbatas tentang harta bersama yang didapat selama perkawinan, melainkan harta bawaan masinng-masing suami istri. Terkait hal tersebut, Damanhuri menegaskan bahwa perjanjian perkawinan terhadap harta bersama yaitu perjanjian tertulis yang disahkan oleh Pegawai Pencatat Nikah, dimana perjanjian tersebut dibuat dengan tujuan untuk mempersatukan atau memisahkan harta kekayaan pribadi masing-masing selama perkawinan berlangsung, sesuai dengan kesepakatan kedua belah pihak. ${ }^{30}$

Berdasarkan penjelasan yang telah diuraikan di atas, ketiga peraturan perundang-undangan yang selama ini menjadi patokan dan pedoman dalam melakukan perjanjian perkawinan, sebatas mengatur tentang harta kekayaan atau harta benda saja

${ }^{28}$ Lihat Pasal 35 Undang-Undang Nomor 1 Tahun 1974 tentang Pekawinan.

${ }^{29}$ Lihat Pasal 36 Undang-Undang Nomor 1 Tahun 1974 tentang Pekawinan.

${ }^{30}$ Damanhuri. Segi-Segi Hukum..., 12.

Ulul Albab: Jurnal Studi dan Penelitian Hukum Islam 
(konsep materialistik). Perjanjian kawin ini, sifatnya memberikan perlindungan bagi pasangan suami istri selama terikat perkawinan dan/ataupun saat ikatan perkawinan tersebut lepas (baca: bercerai).

Berbagai fakta empiris menunjukkan bahwa perceraian tidak hanya perbedaan status sosial atau sengketa harta. Banyak faktor yang menjadi pemicu terjadinya perceraian, diantaranya faktor permasalahan ekonomi, kekerasan dalam rumah tangga (KDRT), perselingkuhan, poligami, dan lain sebagainya. Hal ini menunjukkan bahwa penyebab perceraian tidak hanya sebatas pada persoalan harta dalam perkawinan, akan tetapi juga mengenai hak dan kewajiban suami istri dalam membina sebuah rumah tangga. Perlu dipahami bahwa perkawinan merupakan suatu ikatan yang sah untuk membina rumah tangga dan keluarga yang bahagia, dimana suami dan istri memikul amanah dan tanggung jawab, misalnya saja seorang suami yang bertanggung jawab untuk memberikan nafkah kepada keluarganya, dan seorang istri yang memiliki amanah untuk mengurus semua kebutuhan rumah tangga.

Berdasarkan penjelasan di atas, akan lebih baik jika sebelum melangsungkan perkawinan, pasangan calon suami istri mengetahui dan memahami hak dan kewajiban suami istri dalam sebuah perkawinan. Yahya Harahap dalam hal ini mengemukakan bahwa hak dan kewajiban suami istri terdiri dari: ${ }^{31}$

1. Kedudukan suami istri dalam rumah tangga dan masyarakat. Kedudukan suami istri dalam rumah tangga ataupun dalam pergaulan masyarakat adalah sama atau seimbang. ${ }^{32}$ Artinya,

${ }^{31}$ M. Yahya Harahap, Hukum Perkawinan Nasional Berdasarkan UndangUndang No. 1 Tahun 1974, Peraturan Pemerintah No. 9 Tahun 1975, (Medan: CV. Zahi Trading, 1975), 91-115.

${ }^{32}$ Lihat Pasal 31 ayat (1) Undang-Undang Nomor 1 Tahun 1974 tentang Perkawinan, dan lihat pula Pasal 79 ayat (2) Instruksi Presiden R.I Nomor 1 Tahun 1991 tentang Penyebarluasan Kompilasi hukum Islam. 
tidak ada perbedaan antara laki-laki dan perempuan, karena suami dan istri merupakan dua komponen penting dalam arti kemanusiaan dan dalam melaksanakan fungsi keluarga. Hal ini sejalan dengan prinsip agama Islam, dimana manusia diciptakan dari kejadian yang sama dan memberi kepada manusia kedudukan yang sama derajatnya. Begitu pula dalam sebuah perkawinan, suami istri mempunyai kedudukan harmoni yang sama, tidak ada dominasi dan supremasi di antara keduanya, baik dalam pembinaan rumah tangga maupun pembinaan keturunan. ${ }^{33}$ Pada tataran masyarakat, suami dan istri juga memiliki kedudukan yang sama, dengan artian bahwa suami dan istri mempunyai hak yang legal untuk mengembangkan kemampuan dan profesi masing-masing, ${ }^{34}$ serta bergaul dan bersosialisasi dengan masyarakat. Terkait hal tersebut, perlu dipahami pula bahwa bukan berarti istri dapat bertindak sewenang-wenang dan melakukan sesuatu apapun sesuai dengan keinginannya. Ada batasan-batasan yang harus ditaati oleh istri, dan apapun yang dilakukan oleh istri hendaknya diketahui oleh suami dan atas persetujuan suami pula, terutama dalam hal pengelolaan harta kekayaan.

2. Kemampuan bertindak bagi istri.

Istri memiliki hak untuk melakukan perbuatan hukum, sebagaimana yang diatur di dalam Pasal 31 (2) UU Perkawinan dan Pasal 79 ayat (3) KHI. Aturan tersebut menunjukkan bahwa istri dapat dengan bebas melakukan perbuatan hukum yang bersangkutan dengan kegiatan ekonomi dan bisnis tanpa campur tangan dari suami.

3. Suami sebagai kepala keluarga.

${ }^{33}$ Endang Sumiarni. Kedudukan Suami Istri dalam Perkawinan (Kajian Kesetaraan Jender Melalui Perjanjian Perkawinan). (Yogyakarta: Wonderful Publishing Company, 2004), 13.

${ }^{34}$ Ibid., 13.

Ulul Albab: Jurnal Studi dan Penelitian Hukum Islam 
Pada tataran fungsi dalam membina rumah tangga, suami dalam hal ini berperan sebagai kepala rumah tangga. ${ }^{35}$ Penegasan suami sebagai kepala rumah keluarga merupakan bentuk perbedaan antara suami dan istri dari segi biologis sebagai laki-laki dan perempuan. Hal ini dikarenakan apabila ditinjau dari kejiwaan, suami lebih mempunyai kualitas yang rasional dibandingkan dengan istri yang cenderung bersifat emosional. Terkait hal tersebut, sebagai kepala rumah tangga, suami berkewajiban untuk membimbing istri dan keluarganya, melindungi istri dan mencukupi kebutuhan keluarnya, serta wajib memberikan pendidikan agama dan kesempatan belajar kepada istrinya. ${ }^{36}$

4. Tempat kediaman bersama.

Suami istri harus mempunyai tempat kediaman bersama untuk melaksanakan kewajiban fungsional secara kooperatif, ${ }^{37}$ sebagaimana yang telah tercantum di dalam Pasal 32 Undang-Undang Nomor 1 Tahun 1974 tentang perkawinan, yang isinya sebagai berikut:

(1) Suami isteri harus mempunyai tempat kediaman yang tetap.

(2) Rumah tempat kediaman yang dimaksud dalam ayat (1) pasal ini ditentukan oleh suami istri bersama.

Hal ini dikarenakan suami istri tidak mungkin dapat menjalan tugas atau kewajibannya jika tinggal terpisah, sebab dalam menjalankan kewajiban tersebut, perlu ada kerjasama dan saling membantu diantara kedua belah pihak. Berkenaan dengan hal tersebut, suami wajib menyediakan tempat

${ }^{35}$ Lihat Pasal 105 Kitab Undang-Undang Hukum Perdata, bandingkan dengan Pasal 31 ayat (3) Undang-Undang Nomor 1 Tahun 1974 tentang Perkawinan, dan Pasal 79 ayat (1) Instruksi Presiden R.I Nomor 1 Tahun 1991 tentang Penyebarluasan Kompilasi hukum Islam.

${ }^{36}$ Lihat Pasal 80 Instruksi Presiden R.I Nomor 1 Tahun 1991 tentang Penyebarluasan Kompilasi hukum Islam.

${ }^{37}$ Endang Sumiarni, Kedudukan Suami Istri ....., 16. 
kediaman yang layak bagi keluarganya, sehingga istri dan anak-anaknya merasa aman dan tenteram. ${ }^{38}$

5. yang menukar tempat tinggal.

Pada pasal 32 ayat (2) menentukan bahwa rumah tempat kediaman yang tetap, ditentukan oleh suami istri bersama. Apabila suatu saat istri menuntut tempat kediaman yang tak mungkin dijangkau oleh kemampuan pendapatan suami, istri tetap menuntut rumah tempat kediaman lain dengan persetujuan bersama. Jika tidak dapat dikompromi, suami tidak berhak memberi kata putus sesuai dengan kedudukan yang diberikan kepadanya sebagai kepala keluarga. Suami sebagai kepala keluarga sekedar penyebutan yang bersifat perbedaan fungsional, tetapi bukan sebagai maritale macht (kuasa kepala keluarga). Berdasarkan status sosial ekonomi suami, tuntutan istri terhadap rumah tempat kediaman di luar batas-batas kemampuan suami dapat ditolak.

6. Kewajiban suami istri.

Pada UU Perkawinan dijelaskan bahwa suami istri memikul kewajiban yang luhur untuk menegakkan rumah tangga yang menjadi sendi dasar dari susunan masyarakat. ${ }^{39}$ Pengertian luhur dalam hal ini merupakan pengertian relatif tergantung pada latar belakang sosial budaya masyarakat yang bersangkutan, dan setiap hak yang luhur memerlukan suatu pengorbanan dalam arti luas. ${ }^{40}$

KHI juga mengatur tentang hak dan kewajiban suami istri yaitu suami istri wajib saling mencintai, menghormati, setia, dan memberikan bantuan lahir bathin yang satu kepada yang lain; wajib untuk mengasuh dan memelihara buah

${ }^{38}$ Lihat Pasal 81 ayat $(1,2,3)$ Instruksi Presiden R.I Nomor 1 Tahun 1991 tentang Penyebarluasan Kompilasi Hukum Islam.

${ }^{39}$ Lihat Pasal 30 Undang-Undang Nomor 1 Tahun 1974 tentang Perkawinan.

${ }^{40}$ Endang Sumiarni. Kedudukan Suami Istri ...., 12.

Ulul Albab: Jurnal Studi dan Penelitian Hukum Islam 
hatinya; dan wajib memelihara kehormatan masing-masing. ${ }^{41}$ Kewajiban tersebut harus dilaksanakan, sebab suami istri memiliki kedudukan yang sama, baik di dalam rumah tangga maupun di lingkungan masyarakat, tidak ada perbedaan kwalitas jasmani atau rohani, yang ada hanya perbedaan fungsi (suami sebagai kepala rumah tangga, istri sebagai ibu rumah tangga) saja. Terkait hal itu, tidak alasan untuk saling merendahkan satu sama lain. Hal ini sejalan dengan aturan dalam KUHPerdata yang mengharuskan suami istri untuk saling setia, tolong menolong, dan saling membantu satu sama lain ${ }^{42}$. Definisi setia dari segi hukum berkaitan erat dengan pengertian untuk tidak melakukan suatu perbuatan penghianatan dalam bentuk apapun yang dapat menodai kesucian rumah tangga, misalnya istri tidak curang dan culas serta berhubungan dengan laki-laki lain di belakang suami, dan begitu pula sebaliknya suami juga harus setia terhadap istri dan memperlakukan istri dengan sebaik-baiknya. Berkenaan dengan hal tersebut, hadist riwayat Bukhari dan Muslim dari Abu Hurairah r.a dalam Achmad Azhar Basyir mengemukakan:

"Bersikap baiklah kamu terhadap istri-istrimu sebab orang perempuan diciptakan berkodrat seperti tulang rusuk; yang paling lengkung adalah tulang rusuk bagian atas; apabila kamu biarkan akan tetap meluruskannya, ia akan patah dan apabila kamu biarkan akan tetap lengkung, bersikap baiklah kamu terhadap para istri." 43

Hadist tersebut mengandung makna bahwa seorang suami harus memperlakukan istinya dengan sebaik-baiknya. Perlakuan sebagaimana yang dimaksud dapat berupa : pertama, pemberian nafkah terhadap istri. Kedua, apabila suami marah kepada istri jangan sampai mengeluarkan kata-

${ }^{41}$ Lihat Pasal 77 Instruksi Presiden R.I Nomor 1 Tahun 1991 tentang Penyebarluasan Kompilasi Hukum Islam.

${ }^{42}$ Lihat Pasal 103 Kitab Undang-Undang Hukum Perdata.

${ }^{43}$ Achmad Azhar Basyir, Asas-Asas Hukum...., 58. 
kata buruk dan peringatan terakhir diberikan dengan jalan memukul, akan tetapi jangan sampai memukul pada bagian muka. Ketiga, suami jangan mendiamkan istri dengan tidak mengajaknya berbicara, kecuali di rumah. ${ }^{44}$ Perlakuan baik tidak hanya diterapkan oleh seorang suami, akan tetapi istri juga memiliki kewajiban yang harus dipenuhi terhadap suaminya. Kewajiban tersebut yaitu istri harus berbakti lahir batin kepada suami, menyelenggarakan dan mengatur semua urusan rumah tangga dengan sebaik-baiknya. ${ }^{45}$

Sehubungan dengan penjelasan di atas, kesetian suami istri termasuk pula segala macam penderitaan yang menimbulkan hidup keluarga dalam segala bentuk, seperti sosial ekonomi, menegakkan kerukunan, dan melaksankan kewajiban. Berkenaan dengan hal tersebut, setia berarti kewajiban moral memanfaatkan kepercayaan yang diberikan dengan itikad baik, bahwa tidak ada suatu penyimpangan atau penyelewengan terhadap kepercayaan tersebut baik moral maupun materiial. ${ }^{46}$

Berdasarkan hal tersebut, maka suami istri harus saling membantu antar satu sama lain, artinya harus ada kerjasama antar keduanya serta saling menasehati, dan saling terbuka. Terkait demikian, maka segala sesuatu yang dilakukan oleh suami istri harus berdasarkan persetujuan bersama. hal itu dilakukan agar tercipta saling kepercayaan, sehingga percekcokan dalam rumah tangga dapat dihindari.

7. Kewajiban istri sebagai ibu rumah tangga.

Istri sebagai ibu rumah tangga memiliki kewajiban untuk mengatur segala urusan rumah tangga dengan sebaikbaiknya. Pada Pasal 31 ayat (1) UU Perkawinan, walaupun telah dijelaskan bahwa kedudukan suami istri sama baik

${ }^{44}$ Ibid., 59.

${ }^{45}$ Lihat Pasal 83 Instruksi Presiden R.I Nomor 1 Tahun 1991 tentang Penyebarluasan Kompilasi hukum Islam.

${ }^{46}$ Endang Sumiarni, Kedudukan Suami Istri ....., 17.

Ulul Albab: Jurnal Studi dan Penelitian Hukum Islam 
dalam rumah tangga maupun dalam masyarakat, akan tetapi hal itu bukan berarti menghilangkan tugas fungi istri dalam rumah tangga. Berkaitan dengan hal tersebut, selain istri berkewajiban untuk menjaga hak milik kekayaan suami, istri juga berkewajiban untuk melayani secara lahir bathin, menjaga tingkah laku agar suami merasa nyaman dan betah berada di rumah, sehingga suami tidak ke luar rumah secara terus menerus yang justru menjurus pada perbuatan maksiat.

8. Akibat melalaikan kewajiban.

Suami istri yang melalaikan dan melanggar kewajibankewajbannya, maka dapat mengajukan gugatan ke Pengadilan. Istri mempunyai hak untuk meninggalkan suami, apabila suami melakukan perbuatan yang menyakiti si istri. Pelanggaran kewajiban dalam rumah tangga tidak sepenuhnya terletak pada kesalahan suami, akan tetapi perlu diperhitungkan pula bahwa seorang istri selain berperan sebagai ibu rumah tangga, istri juga dapat bekerja diluar sebagai karyawan atau pegawai di luar rumah. Kewajiban ganda yang dipikul oleh istri, dimungkinkan menjadi pemicu adanya konflik antar sumai istri, dimana istri dapat melalaikan kewajibannya sebagai ibu rumah tangga karena memiliki kesibukan lain di luar rumah. Istri juga dimungkinkan melakukan nusyus terhadap suami. Definisi nusyus yaitu membangkang, artinya membangkang terhadap kewajiban-kewajiban dalam hidup perkawinan, dan hal ini dapat terjadi baik dari istri maupun suami. ${ }^{47}$ Nusyus yang dilakukan oleh istri diantaranya tidak taat kepada suami, tidak mau bertempat tinggal bersama suami, suka menerima tamu orang-orang yang tak disukai suami, sering keluar rumah tanpa izin suami, berselingkuh dengan laki-laki lain di belakang suami, dan lain sebagainya. Berkenaan dengan hal tersebut, selama istri nusyus, maka kewajiban suami terhadap

${ }^{47}$ Achmad Azhar Basyir. Asas-Asas Hukum...., 88.

Vol. 1, No. 2, April 2018, 1-30 
$22 \mid$ Diyah Octhorina Susanti

istrinya untuk memberi nafkah, kiswah, tempat kediaman, biaya rumah tangga, biaya perawatan dan biaya pengobatan bagi istri tidak berlaku, kecuali hal-hal yang berkaitan dengan kepentingan sang anak. 48

Hak dan kewajiban suami istri sebagaimana yang telah diuraikan di atas, sudah seharusnya dipahami dan dilaksanakan oleh pasangan suami istri. Pada perjalanannya, tidak semua perkawinan berjalan mulus sesuai dengan keinginan dari setiap pasangan suami istri. Konflik dan perselisihan dalam rumah tangga seringkali terjadi, terutama berkaitan dengan kewajibankewajiban yang dilalaikan oleh salah satu pasangan.

Terkait demikian, konflik dan perselisihan tersebut pada dasarnya dapat dicegah agar tidak berujung pada perceraian yakni melalui perjanjian perkawinan. Sehubungan dengan hal tersebut, perjanjian perkawinan merupakan sesuatu hal yang penting dan tidak dapat dikesampingkan karena hal ini menyangkut keberlangsungan kehidupan setiap pasangan suami istri. Pada tataran demikian, penulis berasumsi bahwa perjanjian perkawinan bukan hanya sebagai upaya dalam melindungi harta benda masing-masing pihak, akan tetapi juga merupakan upaya untuk memberikan kemanfaatan untuk semua pihak agar tercipta suatu keadilan yang tidak hanya menguntungkan salah satu pihak saja.

Terkait kemanfaatan sebagaimana yang dimaksud di atas, untuk meninjau pentingnya perjanjian perkawinan bagi setiap pasangan suami istri, penulis menggunakan teori utilitis Jeremy Bentham yang dikenal sebagai the father of legal utilitarianism.49 Menurut Bentham dalam Nurhadi, hukum bertujuan untuk mewujudkan apa yang bermanfaat atau yang

${ }^{48}$ Lihat Pasal 84 Instruksi Presiden R.I Nomor 1 Tahun 1991 tentang Penyebarluasan Kompilasi hukum Islam.

${ }^{49}$ Ahmad Ali, Menguak Teori Hukum (Legal Theory) dan Teori Peradilan (Judicial Prudence) termasuk Interpretasi Undang-Undang (Legal Prudence), (Jakarta: Penerbit kencana Jakarta, 2009), 272.

Ulul Albab: Jurnal Studi dan Penelitian Hukum Islam 
sesuai dengan kepentingan orang banyak, pernyataannya yang terkenal adalah the Greatest Happiness for the Greatest Number, artinya kebahagiaan yang terbesar untuk jumlah yang terbanyak. Bentham dalam Nurhadi menaruh perhatian besar terhadap penerapan asas manfaat dalam peraturan perundangundangan sehingga banyak berkarya tentang pokok ini, di antaranya The Theory of Legislation..$^{50}$

Bentham memaknai kemanfaatan (utility) sebagai sesuatu yang dapat dimiliki dan dapat mendatangkan manfaat, keuntungan, kesenangan, dan kebahagiaan, atau sesuatu yang dapat mencegah terjadinya kerusakan, ketidaksenangan, kejahatan, atau ketidakbahagiaan. Nilai kemanfaatan ini ada pada tingkat individu yang menghasilkan kebahagiaan individual maupun masyarakat. ${ }^{51}$ Sehubungan dengan hal tersebut, kemanfaatan adalah tujuan utama dari hukum dan kemanfaatan dalam konteks ini dimaknai sebagai kebahagiaan atau kesenangan (happiness). Sehingga yang ditekankan bukanlah adil tidaknya suatu hukum, melainkan sampai sejauh mana hukum dapat memberikan kemaslahatan kepada manusia. ${ }^{52}$

Merujuk pada teori Bentham tersebut, perjanjian perkawinan merupakan suatu upaya untuk menjamin kepastian hukum kepada masyarakat, terutama kepada pasangan suami istri dan memberikan manfaat bagi masyarakat. Terkait

${ }^{50}$ Nurhadi, Teori Perundang-undangan. Prinsip-prinsip Legislasi, Hukum Perdata dan Hukum Pidana, terjemahan dari Jeremy Bentham The Theory of Legislation. (Bandung: Penerbit Nusamedia \& Penerbit Nuansa, 2006), 1.

${ }^{51}$ Atip Latifulhayat, "Khazanah Jeremy Bentham", Padjadjaran Jurnal Ilmu Hukum, Vol. 2 No. 2, tahun 2015, 413.

52 Dyah Ochtorina Susanti dan S. N. Shoimah, "Urgensi Pencatatan Perkawinan (Perspektif Utilities)", Jurnal Rechtidee, Vol. 11. No. 2, Desember 2016, 175. 
demikian, Damanhuri membagi 2 (dua) manfaat perjanjian perkawinan yakni: ${ }^{53}$

1) Manfaat bagi kehidupan pribadi masing-masing suami istri, berupa kebebasan berkontrak, penegakkan rasa keadilan, peningkatan kualitas kerja, dan peningkatan taraf ekonomi negara;

2) Manfaat dalam hal penyelesaian kasus perkawinan pada lembaga peradilan, berupa penghematan waktu, dimana apabila pihak yang berperkara terikat dalam perjanjian perkawinan. maka tidak perlu adanya pembuktian baik terkait harta bersama maupun hal-hal yang dipermasalahkan, akan tetapi cukup merujuk pada perjanjian perkawinan yang telah dibuat. Manfaat lainnya yakni dapat menghemat biaya. Hal itu dikarenakan dalam konflik rumah tangga yang diikat dengan perjanjian perkawinan, bisa jadi dalam hal harta yang diperoleh selama perkawinan tidak sampai diproses di pengadilan, sebab kedua belah pihak telah menerima sepenuhnya terhadap isi perjanjian perkawinan yang dibuat. Apabila kedua belah pihak menghendaki agar harta bersama dimasukkan dalam putusan bersamaan dengan sengketa perceraian, maka hasil yang diperoleh berupa perdamaian, sehingga tidak memerlukan tahap-tahap pemeriksaan sebagaimana pemeriksaan sengketa perkawinan yang tidak diikat dalam perjanjian perkawinan.

Penjelasan di atas menunjukkan bahwa tujuan dan manfaat utama perjanjian perkawinan yaitu untuk kemaslahatan umat manusia, khususnya bagi pasangan suami istri. Menurut Abu Ishaq al Shatibi dalam Mohammad Daud Ali, kemaslahatan sebagaimana yang dimaksud dapat diwujudkan melalui lima unsur pokok yaitu agama, jiwa, keturunan, akal, dan harta, dan kelima unsur pokok tersebut di dalam kepustakaan disebut al-maqasid al-khamsah atau al-maqasid al-

${ }^{53}$ Damanhuri, Segi-Segi Hukum, ..., 48-56.

Ulul Albab: Jurnal Studi dan Penelitian Hukum Islam 
syari'ah, apabila diterjemahkan dalam bahasa Indonesia, artinya tujuan-tujuan hukum Islam (selanjutnya disebut maqashid syari'ah). ${ }^{54}$ Inti dari maqashid syari'ah yaitu untuk mewujudkan dan memelihara mashlahat umat manusia, dengan kata lain, tujuan hukum Islam adalah kebahagiaan hidup manusia di dunia dan di akhirat kelak, dengan jalan mengambil (segala) yang bermanfaat dan mencegah atau menolak yang mudharat. ${ }^{55}$

Sehubungan dengan penjelasan di atas, pembuatan perjanjian perkawinan hendaknya harus sesuai dengan maqashid syar'iah. Terkait hal tersebut, berikut pemaparan keterkaitan antara perjanjian perkawinan dan maqashid syari'ah yangmeliputi 5 (lima) unsur pokok, diantaranya:

1. Memelihara Agama.

Perjanjian perkawinan dilaksanakan dengan tujuan pertama yakni untuk memelihara agama. Hal ini dikarenakan di dalam agama Islam selain terdapat komponen-komponen aqidah yang merupakan pegangan hidup setiap Muslim, juga memuat akhlaq yang merupakan sikap hidup seorang Muslim, ${ }^{56}$ sehingga perlu dipelihara dan dijaga. Terkait hal tersebut, dalam perjanjian perkawinan, dimungkinkan para pihak memperjanjikan hal apapun bahwa selama perkawinan berlangsung, para pihak berjanji untuk tetap memeluk Agama yang dianutnya. ${ }^{57} \mathrm{Hal}$ ini dilakukan sebagai bentuk pemeliharaan dan penegakan agama Islam.

2. Memelihara Jiwa.

Hukum Islam wajib memelihara hak manusia untuk hidup dan mempertahankan kehidupannya. Salah satu cara untuk mewujudkan hal tersebut yaitu dengan adanya perjanjian perkawinan. Pada isi perjanjian perkawinan, para pihak

${ }^{54}$ Mohammad Daud Ali. Hukum Islam: Pengantar Ilmu Hukum dan Tata Hukum Islam di Indonesia. (Jakarta: Rajawali Pers, 2011), hlm. 61.

${ }^{55} \mathrm{Ibid}$.

${ }^{56}$ Ibid., hlm. 63.

${ }^{57}$ Damanhuri, Segi-Segi Hukum..., 67. 
dapat memperjanjikan segala sesuatu yang berkaitan keselamatan jiwa masing-masing pihak. Hal itu dikarenakan dalam kehidupan berumah tangga, seringkali terjadi percekcokan yang berujung pada kekerasan fisik, mental, hingga kematian. Berdasar demikian, perjanjian perkawinan merupakan langkah solutif, sebagai upaya melindungi jiwa pribadi suami dan istri guna mempertahankan kemaslahatan hidupnya.

3. Memelihara Akal.

Tujuan perjanjian perkawinan menurut maqashid syari'ah selanjutnya yaitu untuk memelihara akal, dimana akal merupakan komponen penting manusia agar dapat berpikir tentang Allah SWT, alam semesta, dan dirinya sendiri serta dapat mengembangkan ilmu pengetahuan dan teknologi. Terkait demikian, maka akal hendaknya digunakan untuk melakukan hal-hal yang bermanfaat, melalui pelarangan dalam mengkonsumsi minum-minuman yang memabukkan atau haram, pemakaian narkoba, dan hal-hal lain yang dapat merusak akal, dimana kesemuanya tersebut dapat dicantumkan di dalam isi perjanjian perkawinan.

4. Memelihara Keturunan.

Perjanjian perkawinan dalam tujuan keempat ini yakni untuk memelihara keturunan. Pemeliharaan keturunan dilakukan agar kemurnian darah dapat dijaga, kelanjutan umat manusia dapat diteruskan, serta meghasilkan keturunan yang berakhlak mulia. Berkenaan dengan demikian, untuk mewujudkan keturunan sebagaimana yang dimaksud, maka kedua belah pihak dapat membuat perjanjian yang isinya terkait pelarangan untuk berzina, berhubungan dengan perempuan atau laki-laki lain yang bukan muhrim, serta larangan dalam berpoligami tanpa persetujuan istri.

5. Memelihara Harta.

Menurut Ajaran Islam, harta merupakan pemberian Allah kepada manusia, agar dapat mempertahankan hidup dan 
melangsungkan kehidupannya, dengan cara memperoleh harta kekayaan secara sah dan hal, serta memelihara harta kekayaan tersebut. ${ }^{58}$ Pada perkawinan, harta merupakan sesuatu hal yang sensitif bagi pasangan suami istri, terutama berkaitan dengan persatuan harta atau percampuran bulat harta kekayaan suami istri. Faktanya, persatuan dan percampuran harta kekayaan tidak sesuai dengan kehidupan keluarga saat ini. Hal ini dikarenakan, tidak hanya suami yang memiliki penghasilkan dari hasil kerjanya, akan tetapi tuntutan zaman dan gaya hidup mendorong para istri untuk berkarir di luar rumah, disamping perannya sebagai ibu rumah tangga, sehingga istri pun kini memiliki penghasilan sendiri. Sehubungan dengan hal tersebut, penghasilkan suami istri yang sama-sama bekerja tentu memiliki nominal yang berbeda, dan dengan adanya persatuan harta, maka suami atau istri berhak untuk menggunakan penghasilan dari keduanya untuk keperluan apapun.

Terkait hal tersebut, tidak jarang salah satu pihak dirugikan, misalnya penghasilan istri lebih besar daripada suami, karena terjadinya persatuan harta, si suai kemudian menggunakan bagian harta istri untuk dipakai mabukmabukan, membeli barang yang sebenarnya bukan menjadi kebutuhan pokok, dan lain sebagainya. Berdasar demikian, maka suami istri dapat membuat perjanjian perkawinan untuk melakukan pemisahan harta dalam perkawinan, sehingga harta suami dan istri tidak bercampur dan dapat dipergunakan untuk keperluan masing-masing pihak.

Perjanjian kawin dapat diperjanjikan selain mengenai harta perkawinan, juga mengenai monogami, hak dan kewajiban suami istri, dan perjanjian lain yang dikehendaki oleh pasangan suami istri.

${ }^{58}$ Mohammad Daud Ali, Hukum Islam: Pengantar..., 64. 
28 Diyah Octhorina Susanti

\section{Kesimpulan}

Terkait uraian diatas, maka dapat disimpulkan bahwa perjanjian kawin yang diatur dalam hukum positif Indonesia hanya merupakan perjanjian yang bersifat materialistik yang hanya mengatur harta pasangan suami istri. Sehubungan dengan hal tersebut, seharusnya perjanjian perkawinan juga mengatur tentang konsep spiritualnya atau hal-hal apa saja yng dapat menimbulkan permasalahan bagi suami istri yang dapat menjadi faktor perceraian dimasukkan dan diatur dalam perjanjian perkawinan. Pada perjanjian kawin dapat memperjanjikan selain mengenai harta perkawinan, misal mengenai perkawinan monogami, hak dan kewajiban suami istri, dan perjanjian lain yang dikehendaki oleh pasangan suami istri. Hal demikian akan membawa manfaat serta melindungi pasangan sumi istri serta meminimalisir terjadinya perselisihan.

Kepada pemerintah dan DPR RI, hendaknya mengadakan pembaharuan terhadap susbtansi perjanjian kawin, tidak hanya memuat perjanjian tentang harta saja, melainkan tegas diterangkan bahwa pasangan suami istri dapat melakukan perjanjian kawin diluar perjanjian tentang harta. Hendaknya dibuat aturan tersendiri yang memuat secara tegas tentang perjanjian kawin dengan mempertimbangkan sisi utilities (kemanfatan) serta berdasar maqashid syari'ah, dan dari sisi kepastian hukum yang bermuara pada jaminan perlindungan bagi pasangan suami istri.

\section{Daftar Pustaka}

Ali, Ahmad. 2009. Menguak Teori Hukum (Legal Theory) dan Teori Peradilan (Judicial Prudence) termasuk Interpretasi UndangUndang (Legal Prudence). Jakarta: Penerbit kencana Jakarta.

Ali, Mohammad Daud. 2011. Hukum Islam: Pengantar Ilmu Hukum dan Tata Hukum Islam di Indonesia.

Ulul Albab: Jurnal Studi dan Penelitian Hukum Islam 
Perjanjian Kawin Sebagai Bentuk .... $\mid 29$

Andasasmita, Komar. 1990. Notaris II Contoh Akta Otentik dan Penjelasannya. Bandung: Ikatan Notaris Indonesia (INI) Daerah Jabar.

Basyir, Achmad Azhar. 2000. Asas-Asas Hukum Muamalat. Yogyakarta: UII Press.

Cindawati. Perkembangan Perjanjian Baku dalam Praktik Perdagangan (Perspektif Hukum Islam dan Perspektif Hukum Positif). Jurnal Jurisdictie Jurnal Hukum dan Syari'ah, Vol. 7 No.2, Desember 2016.

Damanhuri. 2012. Segi-Segi Hukum Perjanjian Perkawinan Harta Bersama. Bandung: CV. Mandar Maju.

Dyah Ochtorina Susanti dan S. N. Shoimah. Urgensi Pencatatan Perkawinan (Perspektif Utilities). Jurnal Rechtidee, Vol. 11. No. 2, Desember 2016.

Harahap, M. Yahya. 1975. Hukum Perkawinan Nasional Berdasarkan Undang-Undang No. 1 Tahun 1974, Peraturan Pemerintah No. 9 Tahun 1975. Medan: CV. Zahi Trading. Instruksi Presiden Republik Indonesia Nomor 1 Tahun 1991 Tentang Penyebarluasan Kompilasi Hukum Islam.

Khazanah. Jeremy Bentham. Padjadjaran Jurnal Ilmu Hukum, Vol. 2 No. 2, tahun 2015.

Marzuki, Peter Mahmud. 2005. Penelitian Hukum. Jakarta: Prenada Media.

Nurhadi. 2006. Teori Perundang-undangan. Prinsip-prinsip Legislasi, Hukum Perdata dan Hukum Pidana, terjemahan dari Jeremy Bentham The Theory of Legislation. Bandung: Penerbit Nusamedia \& Penerbit Nuansa.

Pasaribu, Chairuman, et.al.. 2004. Hukum Perjanjian Dalam Islam. Jakarta: Sinar Grafika.

Prawirohamidjojo, R. Soetojo, et.al. 1987. Hukum Orang dan Keluarga. Bandung: Alumni.

Soebekti, R.. 1994. Pokok-Pokok Hukum Perdata. Jakarta: Intermasa. Soejono, et.al.. 2003. Metode Penelitian Hukum. Jakarta: Rineka Cipta. 
$30 \mid$ Diyah Octhorina Susanti

Soekanto, Soerjono, et.al.. 2004. Penelitian Hukum Normatif: Suatu Tinjauan Singkat. Jakarta: Rajawali Pers.

Subekti, et.al.. 1996. Kitab Undang-Undang Hukum Perdata. Jakarta: PT. Pradnya Paramita.

Sumiarni, Endang. 2004. Kedudukan Suami Istri dalam Perkawinan (Kajian Kesetaraan Jender Melalui Perjanjian Perkawinan). Yogyakarta: Wonderful Publishing Company.

Susanti, Dyah Ochtorina, et.al. 2014. Penelitian Hukum (Legal Research). Jakarta: Sinar Grafika.

Suwondo, Nani. 1992. Kedudukan Wanita Indonesia Dalam Hukum dan Masyarakat. Jakarta: Ghalia Indonesia.

Undang-Undang Nomor 1 Tahun 1974 Tentang Perkawinan.

Valerina JL. Kriekhoff. 2002. Analisis Kontent Dalam Penelitian Hukum : Suatu Telaah Awal. Era Hukum. No, 6., hlm. 22. http://www.notary.my.id/2016/11/pembuatan-perjanjianperkawinan-pasca.html.

https://putusan.mahkamahagung.go.id/main/pencarian/?q=083 6\%2FPdt.G\%2F2017\%2FPA+Bta.

https://putusan.mahkamahagung.go.id/main/pencarian/?q=090 7\%2FPdt.G\%2F2017\%2FPA.Bta.

https://putusan.mahkamahagung.go.id/main/pencarian/?q=251 \%2FPdt.G\%2F2017\%2FPA.Skh. 